\title{
RNAi Crop Protection Advances
}

\author{
Alejandro Hernández-Soto ${ }^{1 *}$, Randall Chacón-Cerdas ${ }^{2}$ \\ 1 Costa Rica Institute of Technology, DOCINADE, Biology School, Biotechnology Research Center. Costa \\ Rica., P.O Box 159-7050 Cartago, Costa Rica; alhernandez@tec.ac.cr (https://orcid.org/0000-0001-9435-5117) \\ 2 Costa Rica Institute of Technology, Biology School, Biotechnology Research Center. Costa Rica., P.O Box \\ 159-7050 Cartago, Costa Rica; rchacon@tec.ac.cr (https://orcid.org/0000-0002-5364-4649) \\ * Correspondence: alhernandez@tec.ac.cr
}

\begin{abstract}
RNAi technology is a versatile, effective, safe, and eco-friendly alternative for crop protection. There is plenty of evidence of its use through Host-induced gene silencing (HIGS) and spray-induced gene silencing (SIGS) techniques to control viruses, bacteria, fungi, insects, and nematodes. As for SIGS, its most significant challenge is achieving stability and avoiding premature degradation of RNAi in the environment or during its absorption in the target organism. One alternative is the encapsulation in liposomes, virus-like particles, polyplex nanoparticles, and bio-clay, which can be obtained through the recombinant production of RNAi in vectors, transgenesis, and micro/nanoencapsulation. The materials must be safe, biodegradable, and stable in multiple chemical environments favoring the controlled release of RNAi. Most of the current research of encapsulated RNAi focuses primarily on oral delivery to control insects by silencing essential genes. The regulation of RNAi technology focuses on risk assessment from different approaches; however, this technology has positive characteristics for its use in agriculture from the economic, environmental, and human health implications. The emergence of alternatives combining RNAi gene silencing with the induction of resistance in crops by elicitation and metabolic control is expected, as well as multiple silencing and biotechnological optimization of its large-scale production.
\end{abstract}

Keywords: RNAi; dsRNA; silencing, encapsulation, liposomes, virus-like particles, polyplex nanoparticles, bio-clay, regulatory.

\section{Introduction}

The world moves towards a more sustainable crop production system that urges specific and efficient tools to battle plant pathogens. RNAi can be used for such purposes. The molecule is used by nature, degrades quickly, can disrupt the pathogen at a genetic specific level, and can complement the current agronomic crop protection practices used for organic, conventional, ecological, or technological production ${ }^{1}$. The reader may be familiar with the concept of DNA and genes located at the nucleus of eukaryote cells, containing the instructions to elaborate organic molecules, mainly proteins. RNA messenger works as an intermediator, carrying the nucleus's message to the cytoplasm to be read by the ribosomes to ensemble the protein. RNAi eukaryotic machinery is a complex system for virus defense and gene expression control, named Post Transcriptional Gene Silencing (PTGS). The system can be triggered by external specific dsRNA resulting in its RNA messenger block before it gets to the ribosome leaving the organism, such as a pathogen, disarmed $^{2}$. The delivery of external dsRNA to disarm the expression system was proven to be natural and bi-directional from plant to pathogen and vice versa cross-kingdom communication $^{3-8}$.

Consequently, RNAi represents an opportunity to emulated or improve the natural plant pathogen control system by providing well-designed external dsRNA 9 . Here we aimed to present advantages in crop protection mediated by RNAi. There are two RNAi plant-based technologies Host-induced gene silencing (HIGS) used since the 90s and 
spray-induced gene silencing (SIGS). Both can provide sustainable solutions to control pathogens, such as insects, viruses, and fungi. We will focus on SIGS because it is becoming an emerging affordable option with a cost reduction of about $0.5-1$ USD per gram ${ }^{10}$; the small amount needed of dsRNA that seems to be near 2-10 grams per hectare; its safety; and fast environmental degradation ${ }^{11-13}$. When dsRNA is applied externally in plants, the plant cells can take it and use it directly to tackle the pathogen through secreted vesicles containing the RNA at the site of infection and plasmodesmata ${ }^{14-16}$. The sprayed RNA amount may vary depending on the target species' sensitivity to RNAi, the capacity for triggering the defense system, and the efficient delivery method. Other challenges for this technology are the need for science-based risk assessment procedures for topical RNAi applications within existing plant protection products legislation; the regulatory aproaches ${ }^{12,17}$; the strategy to use more than one target sequence to avoid resistance uptake method $^{18}$.

\section{Potential targets}

The potential targets of RNAi can be viruses, fungi, bacteria, nematodes, and endogenous genes. We describe next a general table containing several targets to demonstrate that the technology is flexible enough to start exploring other plagues, broader reviews exist in case of interest by the reader ${ }^{19}$

Table 1. Potential targets for spray-induced gene silencing (SIGS) in plants.

\begin{tabular}{|c|c|c|c|}
\hline Target & Experimental evidence & Target genes & Reference \\
\hline \multirow{2}{*}{ Virus } & $\begin{array}{l}\text { dsRNA+clay resulted in BCMV virus resistance for } \\
20 \mathrm{~d}\end{array}$ & $\mathrm{Nib}$ and $\mathrm{CP}$ genes of BCMV & 20 \\
\hline & TMV Tobacco virus resistance for 7-20d & $\mathrm{CP}, \mathrm{P} 126, \mathrm{RP}$ of TMV & 21,22 \\
\hline \multirow{5}{*}{ Fungi } & Inhibits Botrytis cinerea disease & DCL1, DCL2 of Botrytis cinerea & 23 \\
\hline & Efficiently inhibited Fusarium graminearum & $\begin{array}{l}\text { CYP51A, CYP51B, CYP51C of F. gramine- } \\
\text { arum }\end{array}$ & 24 \\
\hline & Sclerotinia sclerotiorum/ Botrytis cinerea & $\begin{array}{l}\text { mRNA splicing, ribosome biogenesis, } \\
\text { protein disulphide oxidoreductase, pe- } \\
\text { roxisomal protein }\end{array}$ & 23 \\
\hline & $\begin{array}{l}\text { Fusarium asiaticum, Botrytis cinerea Magnaporthe oryzae } \\
\text { Colletotrichum truncatum, }\end{array}$ & $\beta_{2}$-tubulin & 25 \\
\hline & $\begin{array}{l}\text { Fusarium oxysporum f. sp. cubense and Mycosphaerella fi- } \\
\text { jiensi, Fusarium }\end{array}$ & $\begin{array}{l}\text { adenylate cyclase, DNA polymerase al- } \\
\text { pha subunit/delta subunit/ CYP51 }\end{array}$ & 26,27 \\
\hline Nematodes & $\begin{array}{l}\text { Caenorhabditis elegans, Radopholus similis, Meloidogyne } \\
\text { artiellia, Meloidogyne incognita, Globodera pallida }\end{array}$ & Several genes & 24 \\
\hline Insects & $\begin{array}{l}\text { Coleopterans are highly sensitive, Hemiptera, Or- } \\
\text { thoptera, Diptera, Hymenoptera, and Lepidoptera } \\
\text { have different responses. }\end{array}$ & Several genes & 25 \\
\hline $\begin{array}{l}\text { Endogenous } \\
\text { plant genes }\end{array}$ & Arabidopsis, Tobacco, poplar, rice & $\begin{array}{l}\text { Transgenes/CHS/EPSPS/STM/WER/ } \\
\text { MYB1/ WRKY23 }\end{array}$ & 30 \\
\hline
\end{tabular}

\section{Encapsulation technology to improve efficiency}


The use of encapsulation technology has improved the effectiveness of gene silencing by designed RNAi. It confers protection and stability to the dsRNA preventing it from undergoing enzymatic or $\mathrm{pH}$ degradation while it is transported to the target cells where the release of the dsRNA and its subsequent transformation into siRNA is required ${ }^{31-33}$. The development of the encapsulation system is related to the target organism, the type of RNAi to be delivered, and its uptake mechanism. According to this review, it is more common to find encapsulation of dsRNA for the control of insects by the oral route since they have an alkaline $\mathrm{pH}$ in the intestine and the presence of RNases in their digestive tract that would degrade naked $\mathrm{RNAi}^{34}$. A similar case occurs for nematodes, with the difference that the $\mathrm{pH}$ in their intestine is acidic ${ }^{35}$. Research in plants and fungi has shown that they are receptive to dsRNA and siRNA $24,36,37$. However, in insects, it has been proposed that silencing is more efficient when long dsRNA ( $>50 \mathrm{bp}$ ) is used compared to sRNA, partly related to the selectivity of its incorporation mechanism ${ }^{38}$.

The encapsulation can be produced by engineered micro-organisms or synthetic micro/nanoparticles ${ }^{39}$ using different materials like proteins ${ }^{40}$, biopolymers ${ }^{41}$, clays ${ }^{31}$ or lipids $^{42}$. Using these materials confers valuable properties for integrating siRNAs in target cells; for instance, capsid proteins that are already recognized by the target organism facilitate the penetration of dsRNAs into their cells, taking advantage of natural infection mechanisms ${ }^{43}$. There are multiple reports of engineered encapsulation systems that transport and protect RNAi, becoming suitable crop protection applications (Table 2).

Table 2. Summary of crop protection application using encapsulation system for RNAi delivery.

\begin{tabular}{|c|c|c|c|}
\hline $\begin{array}{l}\text { Encapsulation } \\
\text { system }\end{array}$ & $\begin{array}{l}\text { Potential crop } \\
\text { protection application }\end{array}$ & Strategy & Reference \\
\hline $\begin{array}{l}\text { Guanylated } \\
\text { 2-(aminoethyl) } \\
\text { methacrylate } \\
\text { (AEMA)/dsRNA } \\
\text { polyplex } \\
\text { nanoparticles. }\end{array}$ & $\begin{array}{l}\text { Insecticide induces } \\
\text { decreased feeding in } \\
\text { Lepidopteran larvae } \\
\text { (Spodoptera exigua); then, } \\
\text { promoting weight loss, } \\
\text { developmental halt, and } \\
\text { mortality. }\end{array}$ & $\begin{array}{l}\text { Increases the RNAi efficiency in targeting the essential } \\
\text { gene chitin synthase B (ChSB), while } \\
\text { preventing degradation of dsRNA in the alkaline gut of } \\
\text { insects and enhancing its cellular uptake in the midgut } \\
\text { cells. }\end{array}$ & 34 \\
\hline $\begin{array}{l}\text { poly-[N-(3- } \\
\text { guanidinopropyl) } \\
\text { methacrylamide] } \\
\text { (pGPMA)/dsRNA } \\
\text { interpolyelectrolyte } \\
\text { nanocomplex. }\end{array}$ & $\begin{array}{l}\text { Ingestion insecticide } \\
\text { regulates gene silencing in } \\
\text { Lepidopteran larvae } \\
\text { (Spodoptera frugiperda), } \\
\text { increasing mortality from } \\
\text { starvation and growth } \\
\text { stunting. }\end{array}$ & $\begin{array}{l}\text { Increased internalization and protection of dsRNA in } \\
\text { insect cells, decreasing the accumulation of target mRNA } \\
\text { due to the knockdown of genes related to vital functions } \\
\text { such as nutrient absorption ( } s f V A T P a s e) \text {, intracellular } \\
\text { transport (sfKIF), and cell division ( } s f C D C 27) \text {. }\end{array}$ & 41 \\
\hline $\begin{array}{l}\text { Chitosan/dsRNA } \\
\text { polyplex nanoparticles }\end{array}$ & $\begin{array}{l}\text { Nematicide can } \\
\text { homogeneously enter the } \\
\text { nematode's body } \\
\text { (Caenorhabditis elegans) } \\
\text { through non-canonical } \\
\text { endocytotic pathways and } \\
\text { attack specific genes. The } \\
\text { combined effect decreases }\end{array}$ & $\begin{array}{l}\text { Increases the RNAi efficiency of gene knockdown } \\
\text { throughout the whole body of the nematode by } \\
\text { introducing intact dsRNA through the Clathrin- } \\
\text { mediated endocytosis pathway, which is different from } \\
\text { the canonical pathway (sid-1 and sid-2) in the study } \\
\text { model. Furthermore, chitosan was shown to effectively } \\
\text { decrease the myosin gene expression, which is critical for } \\
\text { the growth and reproduction of the model nematode. }\end{array}$ & 35 \\
\hline
\end{tabular}


the development of the nematode by the action of the chitosan vehicle.

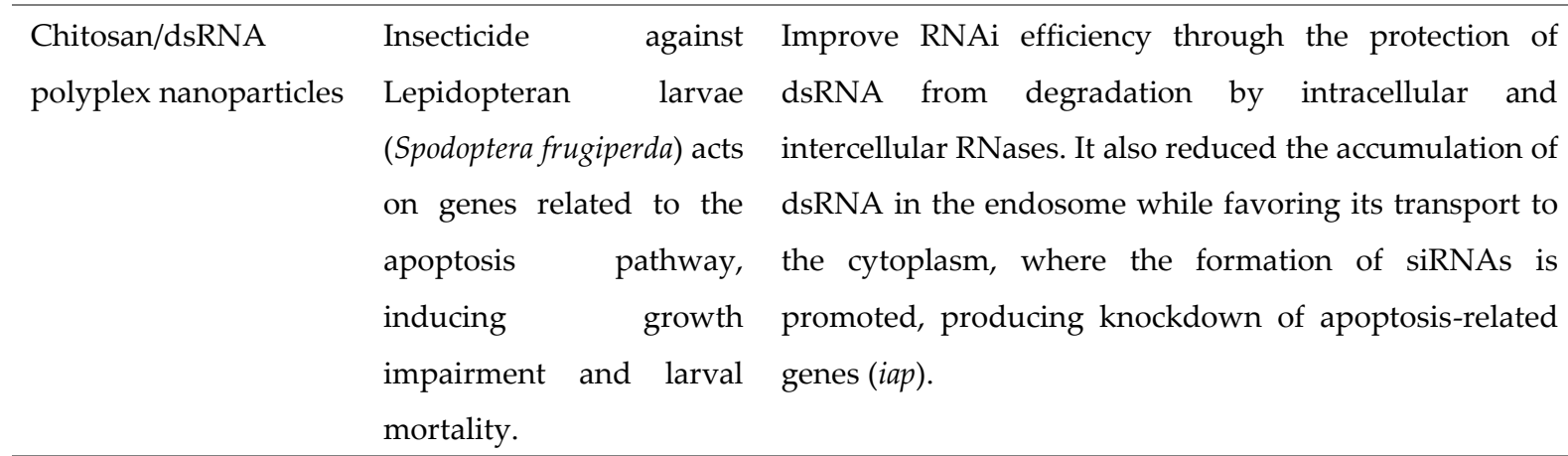

Layered double Develop a topical product Increased persistence of the topical treatment due to the 31 hydroxide $(\mathrm{LDH})$ clay that induces viral strong adhesion of the dsRNA in the vehicle (LDH) and nanosheets/dsRNA resistance in plants of this with the leaves. It also allows the controlled (against PMMoV and release of the biomolecule and confers protection against CMV) using dsRNA environmental degradation while favoring the absorption technology in internalization of dsRNA in the plant. clay nanosheets (BioClay).

Lipofectamine 2000 Insecticide against Promotion of dsRNA internalization in insects through 44 liposomes/dsRNA. Diptera of the genus encapsulation protection, increasing silencing efficiency Drosophila (D. by promoting more significant RNAi accumulation in melanogaster, D. sechellia, larvae. Knockdown of the genes of the VATPase (gut D. yakuba, and D. lumen $\mathrm{pH}$ stabilizer associated with nutrient uptake) and pseudoobscura) acting by $g T u b 23 C$ (mitosis-related g-tubulin protein, essential for ingestion. It attacks microtubule organization).

essential genes of development through knockdown management.

Lipofectamine 2000 Specific insecticide It facilitates the uptake in the insect's gut. It causes 42 liposomes/dsRNA. against larvae and adults significant mortality in larvae and adults by the of Drosophila suzukii reduction in transcript levels of essential genes rps13 combining synergic effect (housekeeping), alpha COP (coatomer subunit for transof multiple gene organelles transport), and vha26 (subunit of the vacuolar knockdown. Oral ATPase). The synergistic action of knockdown of the administration route. rps13 and alpha COP genes significantly increases mortality in the insect.

Liposomes/dsRNA Oral insecticide for the Protection of dsRNA against degradation promoted by 45 control of nymphs of the ribonuclease action of insect saliva. Enhanced Euschistus heros silencing activity of target genes vATPaseA (V-type (hemiptera: proton ATPase catalytic subunit A) and act-2 (muscle pentatomidae), which is actin). 
one of the main soybean

pests in the field.

Recombinant $\begin{aligned} & \text { Flock } \\ & \text { House }\end{aligned}$
FHV/dsRNA

Virus Like Particles (VLP)/dsRNA
Oral insecticide for the control of ants of several genera (Solenopsis invicta (fire ants), Camponotus pennsylvanicus and Camponotus floridanus (carpenter Linepithema ants), (Argentine humile

Tapinoma sessile (odorous ants),

Tetramorium caespitum (pavementom ants), and Monstrous ants) pharaonis (pharaoh ants); inducing the silencing of physiological genes required for the survival of the colony.
Recombinant production in E. colli, which through specific plasmids manufacture capsid proteins of bacteriophages Qß and MS2 and inducible RNAi precursor sequences. The packaging of the dsRNAs in the VLPs protects them from degradation by non-specific environmental organisms and the intestinal RNases of the target organism. It also favors its absorption by lining the gut cells. The silenced genes are related to the viability of the colony, for example, the induction of sterility and individual mortality. VLP carrying dsRNA is sprayed on the ground for spot application or incorporated into the bait. Target genes included $V g R$ (vitellogenin receptor protein), TVXl (telomerase variant XI protein), $P B A N$ (pheromone biosynthesis activating neuropeptide), $\quad P B A N R$ (pheromone biosynthetic activating neuropeptide receptor), WLS (wntless protein), MEGF10 (multiple epidermal growth factor-like domain proteins 10), CHCP (clatherin heavy chain protein), $C D C 7$ (cell division cycle 7-related protein), Cep89 (centrosomal protein $89 \mathrm{kdal}$ ), $\mathrm{PSMBl}$ (beta subunit of the type- 1 proteosome), $A 5 C$ (actin $5 \mathrm{C}$ protein), ATPSD (ATP synthase delta subunit); as well others related with anamorsin, beta actin, and Csp9 proteins

\begin{tabular}{|c|c|c|}
\hline $\begin{array}{l}\text { Ribonucleoprotein } \\
\text { particle (RNP)/dsRNA }\end{array}$ & $\begin{array}{l}\text { Insecticide for control of } \\
\text { the Cotton boll weevil } \\
\text { (Anthonomus grandis) } \\
\text { adults. }\end{array}$ & $\begin{array}{l}\text { Developing a protection and stability system for dsRNA } \\
\text { avoids degradation by nucleases in the insect's gut and } \\
\text { favors rapid cellular incorporation. The above is based on } \\
\text { a chimeric protein PTD-DRBD (peptide transduction } \\
\text { domain - dsRNA binding domain) combined with } \\
\text { dsRNA. This type of resulting protein is known as cell- } \\
\text { penetrating peptides (CPP). }\end{array}$ \\
\hline
\end{tabular}

WO2017/13635

3Al for APSE RNA

Containers

(ARCs) 
According to the data available in the references, we identified four principal encapsulation systems: the formation of liposomes, virus-like particles, polyplex nanoparticles, and bio-clay. As mentioned in table 2, these systems coincide in the biodegradability of the materials, the ability to improve the stability of RNAi, and its synergistic effect to induce control. Figure 1 presents a diagram of the most reported systems.
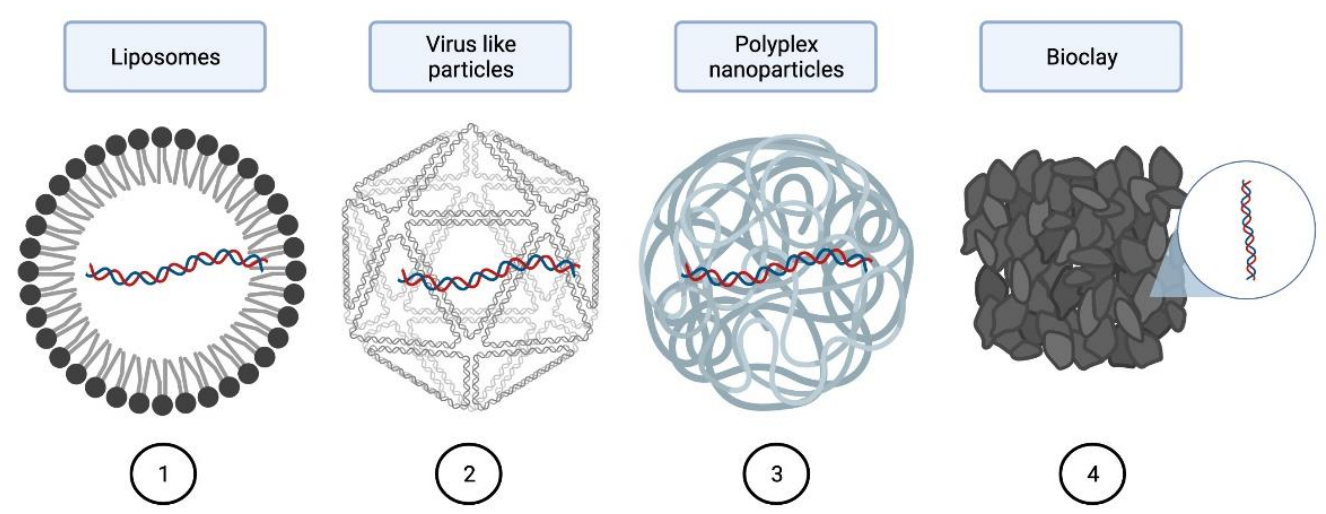

Figure 1. Primary encapsulation system for RNAi delivery.

\section{Regulatory approaches}

The time and cost associated with obtaining the data for a registry of a Biomolecule like dsRNA can be low compared with a conventional pesticide of 4 versus 12 years and $3-7$ million USD versus 280USD ${ }^{46}$. An important consideration is that dsRNA generally have low environmental persistence in soil, sediment, and water ${ }^{47,48}$. The biomolecule shows a record of safe consumption of short and long RNAs in the diet from food and lacks oral immunostimulation ${ }^{11}$. Another positive input when regulating this technology is the technical discussion that has resulted in the last decade where USEPA and OECD (Organisation for Economic Co-operation and Development) propose using and adapting the existing plant protection products norms and procedures as described next. The United States Environmental Protection Agency (EPA) has analyzed addressing this technology based on problem formulation for Human Health and Ecological Risk Assessment. At the same time, OECD proposes using risk assessment to evaluate the toxicity profile and exposure of the molecule by adapting the current regulatory framework for small molecule agrochemicals as a general framework for dsRNA-based agricultural products; and proposes taking into consideration the experience with the review of dsRNA-based GE crops. EFSA literature review on GM plants is a document to be taken into consideration as well.

Table 3. Regulatory approaches

\begin{tabular}{clc}
\hline $\begin{array}{l}\text { Regulatory } \\
\text { Agency }\end{array}$ & \multicolumn{1}{c}{ Proposal } & Reference \\
\hline EPA & $\begin{array}{l}\text { Propose using Problem Formulation- } \\
\text { Risk assessment }\end{array}$ & 49 \\
\hline $\begin{array}{c}\text { European } \\
\text { Food Safety }\end{array}$ & $\begin{array}{l}\text { Do not directly address the spray products, but a literature } \\
\text { Authority } \\
\text { (EFSA) }\end{array}$ & review focus on RNAi-based GM plants and Risk Assessment \\
\hline
\end{tabular}


Propose using risk assessment to evaluate the toxicity profile and exposure, by using the current regulatory framework for OECD small molecule agrochemicals as a general framework for dsRNA-based agricultural products. Proposes using the experience with the review of dsRNA-based GE crops

\section{Conclusions and future perspectives}

RNAi technology is a powerful and versatile alternative for pest and disease control in crops. Its use in the agricultural field extends to viruses, bacteria, fungi, insects, nematodes, and plants. It grows steadily with other complementary technologies such as the recombinant production of RNAi in vectors, transgenesis, and micro/nanoencapsulation of candidate si/dsRNA. The main issue avoiding its adoption in the past was the cost of production and stability. The cost of production is getting lower with the development of new technologies, while stability encapsulation strategies provide a solution to avoid degradation.

Encapsulation of RNAi in liposomes, virus-like particles, polyplex nanoparticles, and bio-clay have gained relevance in the last decade because they confer protection against degradation. Reducing this degradation has been a challenge for the evolution of this technology. This degradation occurs on naked dsRNAs because of environmental exposure or the action of enzymes and the $\mathrm{pH}$ level of the target organism. Encapsulation also provides stability to the dsRNA and sometimes favors cell uptake. Some of the materials used for encapsulation provide additive effects on pest control; however, most of them are innocuous, biodegradable, and stable in multiple chemical environments favoring the controlled release of RNAi. Our review found multiple reports of this technology applied mainly for the control of insects, where the predominant administration mechanism is the oral route using spray-induced gene silencing (SIGS) or the application of encapsulation on baits.

Candidate genes for targeted silencing coincide in essential genes related to enzymes involved in cell division (e.g., CDC27, gTub23C, TVX1, Cep89), cell transport (e.g., KIF, alpha COP), structure formation (e.g., ChSB, act- 2, MEGF10, A5C), and ionic balance and nutrient absorption (e.g., V-ATPase, vha26,); then, producing mortality in the target species.

Current regulations on products developed with RNAi technology focus on assessing their risk from different approaches. However, based on the characteristics of these biomolecules and their proven safety in non-target organisms, a favorable position is predicted for the use of this technology in agriculture, where the will to regulate is optimistic regarding the economic and environmental advantages and its low risks associated with human health. The regulatory landscape can allow the safe adoption of this technology with the current decision-making based on risk assessment. However, a harmonized approach will be needed to enable adoption and avoid trade disruptions soon.

Together with the positive evolution in regulatory, the emergence of more interdisciplinary alternatives that combine gene silencing by RNAi is also expected. For instance, the induction of resistance in crops by elicitation and metabolic control methods, using the strengths of both. Following this approach, we are developing a technology that uses elicitor nanoparticles made of natural polymers to induce defense in the plants, which will also carry a double control mechanism based on RNAi to unblock inhibitors of systemic defense against systemic defense pathogenic species of the genus Fusarium. There is also interest in the scientific community to produce multiple knockdowns that protect systemically against a consortium of pathogens under the same application. Another challenge for this technology is to keep reducing production costs, for which biotechnology is emerging as one of the main allies to produce profitably and on a large scale. 


\begin{abstract}
Author Contributions: Conceptualization, A.H-S., R.C-C.; writing-original draft preparation, A.H-S., R.C-C.; writing - review and editing, A.H-S., R.C-C.; visualization, A.H-S., R.C-C. All authors have read and agreed to the published version of the manuscript.

Funding: This article is part of the Doctoral Thesis of the first author, Doctorado en Ciencia Naturales para el Desarrollo (DOCINADE), Instituto Tecnológico de Costa Rica (TEC), Universidad Nacional, Universidad Estatal a Distancia, Cartago, Costa Rica. Also, it is part of the Doctoral Thesis of the second author, Doctorado Académico en Ingeniería (DAI), Instituto Tecnológico de Costa Rica, Universidad de Costa Rica (Project ID 1510120, funded by Vice-presidency of Research and Extension at TEC).
\end{abstract}

Institutional Review Board Statement: Not applicable.

Informed Consent Statement: Not applicable.

Data Availability Statement: Not applicable.

Conflicts of Interest: The authors declare no conflict of interest.

\title{
References
}

(1) Hernández-Soto, A.; Echeverría-Beirute, F.; Guzmán-Hernández, T. The RNAi as a Tool to Control Tropical Pathogens. Agronomía Mesoamericana 2021, 32 (1), 326-337. https://doi.org/10.15517/am.v32i1.40896.

(2) Sneha Yogindran and Manchikatla Venkat Rajam. RNAi for Crop Improvement Sneha. In Plant Biology and Biotechnology: Volume II: Plant Genomics and Biotechnology; Bahadur, B., Rajam, M. V., Sahijram, L., Krishnamurthy, K. v., Eds.; 2015; Vol. II, pp 623-637. https://doi.org/10.1007/978-81-322-2283-5_31.

(3) Wang, M.; Weiberg, A.; Lin, F. M.; Thomma, B. P. H. J.; Huang, H. da; Jin, H. Bidirectional Cross-Kingdom RNAi and Fungal Uptake of External RNAs Confer Plant Protection. Nature Plants 2016, 2 (10), 16151. https://doi.org/10.1038/nplants.2016.151.

(4) Cai, Q.; He, B.; Kogel, K.-H.; Jin, H. Cross-Kingdom RNA Trafficking and Environmental RNAi - Natures Blueprint for Modern Crop Protection Strategies. Curr Opin Microbiol 2018, 46, 58-64. https://doi.org/doi:10.1016/j.mib.2018.02.003.

(5) Castillo-González, C.; Zhang, X. The Trojan Horse of the Plant Kingdom. Cell Host and Microbe 2018, 24 (1), 1-3. https://doi.org/10.1016/j.chom.2018.06.015.

(6) Zhao, Y.; Liang, X.; Zhou, J.-M. Small RNA Trafficking at the Forefront of Plant-Pathogen Interactions. F1000Research 2018, 7 (0), 1633. https://doi.org/10.12688/f1000research.15761.1.

(7) Cai, Q.; Qiao, L.; Wang, M.; He, B.; Lin, F.-M.; Palmquist, J.; Jin, H. Plants Send Small RNAs in Extracellular Vesicles to Fungal Pathogen to Silence Virulence Genes. Science 2018, 360 (June), 1126-1129. https://doi.org/10.1126/science.aar4142.

(8) Weiberg, A.; Wang, M.; Lin, F.-M.; Zhao, H.; Zhang, Z.; Kaloshian, I.; Huang, H.-D.; Jin, H.; Khaloshian, I.; Huang, H.-D.; Jin, H. Fungal Small RNAs Suppress Plant Immunity by Hijacking Host. Science (New York, N.Y.) 2014, 342 (6154), 118-123. https://doi.org/10.1126/science.1239705.Fungal.

(9) Giudice, G.; Moffa, L.; Varotto, S.; Cardone, M. F.; Bergamini, C.; de Lorenzis, G.; Velasco, R.; Nerva, L.; Chitarra, W. Novel and Emerging Biotechnological Crop Protection Approaches. Plant Biotechnology Journal 2021, 1-16. https://doi.org/10.1111/pbi.13605. 
(10) Taning, C. N. T.; Arpaia, S.; Christiaens, O.; Dietz-Pfeilstetter, A.; Jones, H.; Mezzetti, B.; Sabbadini, S.; Sorteberg, H. G.; Sweet, J.; Ventura, V.; Smagghe, G. RNA-Based Biocontrol Compounds: Current Status and Perspectives to Reach the Market. Pest Management Science 2020, 76 (3), 841-845. https://doi.org/10.1002/ps.5686.

(11) Rodrigues, T. B.; Petrick, J. S. Safety Considerations for Humans and Other Vertebrates Regarding Agricultural Uses of Externally Applied RNA Molecules. Frontiers in Plant Science 2020, 11 (April), 1-12. https://doi.org/10.3389/fpls.2020.00407.

(12) Zotti, M.; dos Santos, E. A.; Cagliari, D.; Christiaens, O.; Taning, C. N. T.; Smagghe, G. RNA Interference Technology in Crop Protection against Arthropod Pests, Pathogens and Nematodes. Pest Management Science. 2018, pp 1239-1250. https://doi.org/10.1002/ps.4813.

(13) Mezzetti, B.; Smagghe, G.; Arpaia, S.; Christiaens, O.; Dietz-Pfeilstetter, A.; Jones, H.; Kostov, K.; Sabbadini, S.; Opsahl-Sorteberg, H.-G.; Ventura, V.; Taning, C. N. T.; Sweet, J. RNAi: What Is Its Position in Agriculture? Journal of Pest Science 2020, 93 (4), 1125-1130. https://doi.org/10.1007/s10340-020-01238-2.

(14) Rutter, B. D.; Innes, R. W. Extracellular Vesicles as Key Mediators of Plant-Microbe Interactions. Current Opinion in Plant Biology. Elsevier Ltd 2018, pp 16-22. https://doi.org/10.1016/j.pbi.2018.01.008.

(15) Song, X. S.; Gu, K. X.; Duan, X. X.; Xiao, X. M.; Hou, Y. P.; Duan, Y. B.; Wang, J. X.; Yu, N.; Zhou, M. G. Secondary Amplification of SiRNA Machinery Limits the Application of Spray-Induced Gene Silencing; 2018 ; Vol. 19. https://doi.org/10.1111/mpp.12728.

(16) Reagan, B. C.; Ganusova, E. E.; Fernandez, J. C.; McCray, T. N.; Burch-Smith, T. M. RNA on the Move: The Plasmodesmata Perspective. Plant Science 2018, 275, 1-10. https://doi.org/10.1016/j.plantsci.2018.07.001.

(17) Mezzetti, B.; Smagghe, G.; Arpaia, S.; Christiaens, O.; Dietz-Pfeilstetter, A.; Jones, H.; Kostov, K.; Sabbadini, S.; Opsahl-Sorteberg, H. G.; Ventura, V.; Taning, C. N. T.; Sweet, J. RNAi: What Is Its Position in Agriculture? Journal of Pest Science 2020, 93 (4), 1125-1130. https://doi.org/10.1007/s10340-020-01238-2.

(18) Wytinck, N.; Manchur, C. L.; Li, V. H.; Whyard, S.; Belmonte, M. F. DsRNA Uptake in Plant Pests and Pathogens: Insights into RNAi-Based Insect and Fungal Control Technology. Plants 2020, 9 (12), 1-17. https://doi.org/10.3390/plants9121780.

(19) Rosa, C.; Kuo, Y.-W.; Wuriyanghan, H.; Falk, B. W. RNA Interference Mechanisms and Applications in Plant Pathology. Annual Review of Phytopathology 2018, 56 (1), 581-610. https://doi.org/10.1146/annurev-phyto-080417050044 .

(20) Worrall, E. A.; Bravo-Cazar, A.; Nilon, A. T.; Fletcher, S. J.; Robinson, K. E.; Carr, J. P.; Mitter, N. Exogenous Application of RNAi-Inducing Double-Stranded RNA Inhibits Aphid-Mediated Transmission of a Plant Virus. Frontiers in Plant Science 2019, 10 (March). https://doi.org/10.3389/fpls.2019.00265.

(21) Konakalla, N. C.; Kaldis, A.; Berbati, M.; Masarapu, H.; Voloudakis, A. E. Exogenous Application of DoubleStranded RNA Molecules from TMV P126 and CP Genes Confers Resistance against TMV in Tobacco. Planta 2016, 244 (4), 961-969. https://doi.org/10.1007/s00425-016-2567-6.

(22) Niehl, A.; Soininen, M.; Poranen, M. M.; Heinlein, M. Synthetic Biology Approach for Plant Protection Using DsRNA. Plant Biotechnology Journal 2018, 16 (9), 1679-1687. https://doi.org/10.1111/pbi.12904.

(23) McLoughlin, A. G.; Wytinck, N.; Walker, P. L.; Girard, I. J.; Rashid, K. Y.; de Kievit, T.; Fernando, W. G. D.; Whyard, S.; Belmonte, M. F. Identification and Application of Exogenous DsRNA Confers Plant Protection against Sclerotinia Sclerotiorum and Botrytis Cinerea. Scientific Reports 2018, 8 (1), 1-14. https://doi.org/10.1038/s41598-018-25434-4.

(24) Koch, A.; Biedenkopf, D.; Furch, A.; Weber, L.; Rossbach, O.; Abdellatef, E.; Linicus, L.; Johannsmeier, J.; Jelonek, L.; Goesmann, A.; Cardoza, V.; McMillan, J.; Mentzel, T.; Kogel, K. H. An RNAi-Based Control of Fusarium 
Graminearum Infections Through Spraying of Long DsRNAs Involves a Plant Passage and Is Controlled by the Fungal Silencing Machinery. PLoS Pathogens 2016, 12 (10), 1-22. https://doi.org/10.1371/journal.ppat.1005901.

(25) Gu, K. X.; Song, X. S.; Xiao, X. M.; Duan, X. X.; Wang, J. X.; Duan, Y. B.; Hou, Y. P.; Zhou, M. G. A $\beta 2$-Tubulin DsRNA Derived from Fusarium Asiaticum Confers Plant Resistance to Multiple Phytopathogens and Reduces Fungicide Resistance. Pesticide Biochemistry and Physiology 2019, 153 (September), 36-46. https://doi.org/10.1016/j.pestbp.2018.10.005.

(26) Mumbanza, F. M.; Kiggundu, A.; Tusiime, G.; Tushemereirwe, W. K.; Niblett, C.; Bailey, A. In Vitro Antifungal Activity of Synthetic DsRNA Molecules against Two Pathogens of Banana, Fusarium Oxysporum f. Sp. Cubense and Mycosphaerella Fijiensis. Pest Management Science 2013, 69 (10), 1155-1162. https://doi.org/10.1002/ps.3480.

(27) Höfle, L.; Biedenkopf, D.; Werner, B. T.; Shrestha, A.; Jelonek, L.; Koch, A. Study on the Efficiency of DsRNAs with Increasing Length in RNA-Based Silencing of the Fusarium CYP51 Genes. RNA Biology 2020, 17 (4), $463-$ 473. https://doi.org/10.1080/15476286.2019.1700033.

(28) Fire, A.; Xu, S.; Montgomery, M. K.; Kostas, S. A.; Driver, S. E.; Mello, C. C. Potent and Specific Genetic Interference by Double-Stranded RNA in Caenorhabditis Elegans. Nature 1998, 391 (6669), 806-811. https://doi.org/10.1038/35888.

(29) Christiaens, O.; Whyard, S.; Vélez, A. M.; Smagghe, G. Double-Stranded RNA Technology to Control Insect Pests: Current Status and Challenges. Frontiers in Plant Science 2020, 11 (April), 1-10. https://doi.org/10.3389/fpls.2020.00451.

(30) Dubrovina, A. S.; Kiselev, K. v. Exogenous RNAs for Gene Regulation and Plant Resistance. International Journal of Molecular Sciences 2019, 20 (9). https://doi.org/10.3390/ijms20092282.

(31) Mitter, N.; Worrall, E. A.; Robinson, K. E.; Li, P.; Jain, R. G.; Taochy, C.; Fletcher, S. J.; Carroll, B. J.; Lu, G. Q.; Xu, Z. P. Clay Nanosheets for Topical Delivery of RNAi for Sustained Protection against Plant Viruses. Nature Plants 2017, 3 (January). https://doi.org/10.1038/nplants.2016.207.

(32) Gurusamy, D.; Mogilicherla, K.; Palli, S. R. Chitosan Nanoparticles Help Double-Stranded RNA Escape from Endosomes and Improve RNA Interference in the Fall Armyworm, Spodoptera Frugiperda. Archives of Insect Biochemistry and Physiology 2020, 104 (4), 1-15. https://doi.org/10.1002/arch.21677.

(33) Killmer, John; Kumar, Anil; McLaughlin, Patrick. D;Humberto, J. P. Methods and Compositions for Controlling Pests. PCT/US2017/015861 Filed January 31, 2017, and issued in process., 2017.

(34) Christiaens, O.; Tardajos, M. G.; Reyna, Z. L. M.; Dash, M.; Dubruel, P.; Smagghe, G. Increased RNAi Efficacy in Spodoptera Exigua via the Formulation of DsRNA with Guanylated Polymers. Frontiers in Physiology 2018, 9 (APR), 1-13. https://doi.org/10.3389/fphys.2018.00316.

(35) Lichtenberg, S. S.; Tsyusko, O. v.; Palli, S. R.; Unrine, J. M. Uptake and Bioactivity of Chitosan/Double-Stranded RNA Polyplex Nanoparticles in Caenorhabditis Elegans. Environmental Science and Technology 2019, 53 (7), 38323840. https://doi.org/10.1021/acs.est.8b06560.

(36) Wang, K.; Peng, Y.; Pu, J.; Fu, W.; Wang, J.; Han, Z. Variation in RNAi Efficacy among Insect Species Is Attributable to DsRNA Degradation in Vivo. Insect Biochemistry and Molecular Biology 2016, 77, 1-9. https://doi.org/10.1016/j.ibmb.2016.07.007.

(37) Wang, M.; Weiberg, A.; Lin, F. M.; Thomma, B. P. H. J.; Huang, H. da; Jin, H. Bidirectional Cross-Kingdom RNAi and Fungal Uptake of External RNAs Confer Plant Protection. Nature Plants 2016, 2 (10), 1-10. https://doi.org/10.1038/nplants.2016.151.

(38) Ivashuta, S.; Zhang, Y.; Wiggins, B. E.; Ramaseshadri, P.; Segers, G. C.; Johnson, S.; Meyer, S. E.; Kerstetter, R. A.; McNulty, B. C.; Bolognesi, R.; Heck, G. R. Environmental RNAi in Herbivorous Insects. Rna 2015, 21 (5), 840850. https://doi.org/10.1261/rna.048116.114. 
(39) Kolliopoulou, A.; Taning, C. N. T.; Smagghe, G.; Swevers, L. Viral Delivery of DsRNA for Control of Insect Agricultural Pests and Vectors of Human Disease: Prospects and Challenges. Frontiers in Physiology 2017, 8 (JUN), 1-24. https://doi.org/10.3389/fphys.2017.00399.

(40) Gillet, F. X.; Garcia, R. A.; Macedo, L. L. P.; Albuquerque, E. V. S.; Silva, M. C. M.; Grossi-de-Sa, M. F. Investigating Engineered Ribonucleoprotein Particles to Improve Oral RNAi Delivery in Crop Insect Pests. Frontiers in Physiology 2017, 8 (APR), 1-14. https://doi.org/10.3389/fphys.2017.00256.

(41) Parsons, K. H.; Mondal, M. H.; McCormick, C. L.; Flynt, A. S. Guanidinium-Functionalized Interpolyelectrolyte Complexes Enabling RNAi in Resistant Insect Pests. Biomacromolecules 2018, 19 (4), $1111-1117$. https://doi.org/10.1021/acs.biomac.7b01717.

(42) Taning, C. N. T.; Christiaens, O.; Berkvens, N.; Casteels, H.; Maes, M.; Smagghe, G. Oral RNAi to Control Drosophila Suzukii: Laboratory Testing against Larval and Adult Stages. Journal of Pest Science 2016, 89 (3), 803 814. https://doi.org/10.1007/s10340-016-0736-9.

Taning, C. N. T.; Christiaens, O.; Li, X. X.; Swevers, L.; Casteels, H.; Maes, M.; Smagghe, G. Engineered Flock House Virus for Targeted Gene Suppression through RNAi in Fruit Flies (Drosophila Melanogaster) in Vitro and in Vivo. Frontiers in Physiology 2018, 9 (JUL), 1-13. https://doi.org/10.3389/fphys.2018.00805.

(44) Whyard, S.; Singh, A. D.; Wong, S. Ingested Double-Stranded RNAs Can Act as Species-Specific Insecticides. Insect Biochemistry and Molecular Biology 2009, 39 (11), 824-832. https://doi.org/10.1016/j.ibmb.2009.09.007.

(45) Castellanos, N. L.; Smagghe, G.; Sharma, R.; Oliveira, E. E.; Christiaens, O. Liposome Encapsulation and EDTA Formulation of DsRNA Targeting Essential Genes Increase Oral RNAi-Caused Mortality in the Neotropical Stink Bug Euschistus Heros. Pest Management Science 2019, 75 (2), 537-548. https://doi.org/10.1002/ps.5167.

(46) Taning, C. N. T.; Arpaia, S.; Christiaens, O.; Dietz-Pfeilstetter, A.; Jones, H.; Mezzetti, B.; Sabbadini, S.; Sorteberg, H. G.; Sweet, J.; Ventura, V.; Smagghe, G. RNA-Based Biocontrol Compounds: Current Status and Perspectives to Reach the Market. Pest Management Science 2020, 76 (3), 841-845. https://doi.org/10.1002/ps.5686.

(47) Parker, K. M.; Barragán Borrero, V.; van Leeuwen, D. M.; Lever, M. A.; Mateescu, B.; Sander, M. Environmental Fate of RNA Interference Pesticides: Adsorption and Degradation of Double-Stranded RNA Molecules in Agricultural Soils. Environmental Science and Technology 2019, 53 (6), 3027-3036. https://doi.org/10.1021/acs.est.8b05576.

(48) Bachman, P.; Fischer, J.; Song, Z.; Urbanczyk-Wochniak, E.; Watson, G. Environmental Fate and Dissipation of Applied DsRNA in Soil, Aquatic Systems, and Plants. Frontiers in Plant Science $2020,11$. https://doi.org/10.3389/fpls.2020.00021.

(49) EPA. United States Environmental Protection Agency. RNAi Technology: Program Formulation for Human Health and Ecological Risk Assessment. FIFRA Scientific Advisory Panel Meeting 2014, January, 1-77.

(50) Christiaens, O.; Dzhambazova, T.; Kostov, K.; Arpaia, S.; Joga, M. R.; Urru, I.; Sweet, J.; Smagghe, G. Literature Review of Baseline Information on RNAi to Support the Environmental Risk Assessment of RNAi-based GM Plants. EFSA Supporting Publications 2018, 15 (5), 173p. https://doi.org/10.2903/sp.efsa.2018.en-1424. 